\title{
KAJIAN FAKTOR - FAKTOR PRODUKSI PADA USAHATANI PADI \\ DAN PILIHAN TANAMAN PADI DI DESA GLONGGONG KECAMATAN GONDANG, KABUPATEN SRAGEN
}

THE RESEARH ON RICE FARMING PRODUCTION AND RICE SELECTION FACTORS IN GLONGGONG VILLAGE GONDANG REGION SRAGEN DICTRICT

\author{
Endang Sri Sudalmi, JM. Sri Hardiatmi
}

\begin{abstract}
Absrak
Penelitian ini berjudul : Kajian Faktor - Faktor Produksi Pada Usahatani Padi Dan Pilihan Tanaman Padi Di Desa Glonggong, Kecamatan Gondang, Kabupaten Sragen yang bertujuan untuk : (1) mengkaji faktor-faktor produksi terhadap hasil produksi padi; (2) untuk mengetahui faktor produksi yang berpengaruh terhadap hasil produksi padi; dan (3) untuk mengetahui alasan petani selalu menanam padi dalam satu tahun.

Metode penelitian yang digunakan adalah diskriptif. Pengambilan data dengan wawancara dan pencatatan. Jumlah petani sampel sebanyak 20 petani pemilik penggarap.

Hasil penelitian yang diperoleh :

1. Faktor-Faktor Produksi Usahatani Padi yaitu luas lahan garapan, pendidikan petani, penggunaan pupuk dan penggunaan obat secara bersama-sama memberikan pengaruh yang sangat nyata terhadap hasil produksi usahatani padi.

2. Luas lahan garapan petani berpengaruh sangat nyata terhadap hasil produksi usahatani padi.

3. Pendidikan petani, penggunaan pupuk dan penggunaan obat berpengaruh tidak nyata (ns) terhadap hasil produksi usahatani padi.

4. Alasan petani dalam 1 tahun selalu menanam tanaman padi :

a. Tanahnya subur.

b. Pengairannya baik dan lancar.

c. Menanam tanaman padi mudah.

d. Beras merupakan makanan pokok.

e. Menanam tanaman padi merupakan tradisi atau turun temurun.

f. Hasil tanaman padi bagus atau menguntungkan.

g. Kalau sudah menanam padi tidak usah membeli beras yang merupakan kebutuhan keluarga sehari-hari.
\end{abstract}

Kata Kunci : faktor-faktor produksi dan usahatani padi 


\title{
THE RESEARH ON RICE FARMING PRODUCTION AND RICE SELECTION FACTORS IN GLONGGONG VILLAGE GONDANG REGION SRAGEN DICTRICT
}

\author{
Endang Sri Sudalmi, J.M Sri Hardiatmi
}

\begin{abstract}
Absract
This study is entitled: The Research on Rice Farming and Rice Selection Factors in Glonggong Village Gondang Region Sragen District. The aims of this research are: (1) To study the production factors of the rice farming production; (2) To figure out the production factors which affect the rice farming production; and (3) to know the reason why the farmer always choose to plant rice in the whole years.

This research use descriptive method. The data is taken by conducting interviews and note taking. The numbers of the farmer as the samples are 20 farmer (land owner and cultivator).

The results of this research are:

1. The factors of rice farming are the area of the cultivated land, educational background of the farmers, the use of the fertilizer and the medicine altogether. They give real effect toward the rice farming production.

2. The area of cultivated land has significant effect toward the rice farming production.

3. The farmer educational background and the use of the fertilizer and the medicine altogether have no significant effect toward the rice farming production.

4. The reasons why the farmer choose to plant rice on the whole years are:

a. The land is fertile.

b. The irrigation is good and runs well.

c. It is easy to plant rice.

d. Rice is categorized as the main and most consumed food.

e. It has been a tradition and heritage from ancestors in that region to plant rice.

$f$. The harvest of the rice farming is good and profitable.

g. The farmers don't need to buy rice as the main food, for they have produced the rice by themselves.
\end{abstract}

Key words: Production factors and rice farming 


\section{PENDAHULUAN}

\subsection{Latar Belakang}

Bertambahnya penduduk Indonesia akan diikuti dengan meningkatnya kebutuhan pangan atau hasil bumi. Namun luas lahan bersifat relatif tetap bahkan berkurang akibat adanya revolusi industri. Hal ini menyebabkan terjadinya ketimpangan antara produksi dengan kebutuhan yang semakin meningkat.

Mosher, A.T. (1983), mengatakan bahwa pendapatan petani tergantung pada luas lahan, tenaga kerja yang digunakan, bibit, pupuk, pestisida yang digunakan dalam proses produksi.

Dalam proses produksi, petani dipengaruhi oleh berbagai faktor. Faktor petani sebagai manajer usahatani seperti umur, jenis kelamin, tingkat pendidikan, juga faktor luar seperti kemajuan teknologi tingkat harga, hal ini sangat menentukan petani untuk berproduksi. Petani sebagai juru tani, sangat dipengaruhi oleh keadaan fisik yang mempunyai tugas mengatur, melaksanakan pekerjaan dan mengawasi kegiatan-kegiatan teknis dari usahataninya sendiri, misalnya : pembuatan pesemaian, pengolahan tanah, penanam, dan seterusnya. Di Desa Gonggong, Kecamatan Gondang, Kabupaten Sragen, terletak di Timur Kota Surakarta. Merupakan daerah berkembang, dalam satu tahun pada umumnya petani menanam padi dari Musim Tanam I, Musim Tanam II, dan Musim Tanam III. Luas lahan, Pendidikan petani, dan penggunaan faktor-faktor produksi yang berbeda akan berpengaruh terhadap produksi yang dihasilkan. Satu tahun petani selalu menanam tanaman padi tidak ada rotasi dengan tanaman selain padi. Untuk itu peneliti ingin mengkaji faktor-faktor produksi yang berpengaruh terhadap produksi padi dan alasan petani satu tahun selalu menanam padi.

\subsection{Perumusan Masalah}

Berdasarkan latar belakang di atas dapat dirumuskan permasalahan dalam penelitian ini sebagai berikut: 
a. Faktor-faktor produksi padi apa yang brpengaruh terhadap produksi padi ?

b. Alasan apa petani dalam satu tahun selalu menanam tanaman padi ?

\subsection{Tujuan Penelitian}

Tujuan dari penelitian adalah :

a. Untuk mengetahui faktor-faktor produksi usahatani padi yang berpengaruh terhadap hasil produksi usahatani padi.

b. Untuk mengetahui alasan petani dalam satu tahun selalu menanam tanaman padi.

\section{METODE PENELITIAN}

\section{Jenis Penelitian}

Dalam penelitian ini merupakan penelitian kualitatif yang cenderung menggunakan jenis penelitian diskriptif. Menurut Koentjaraningrat pada dasarnya mengatakan bahwa :

Penelitian deskriptif yaitu penelitian ini bertujuan untuk menggambarkan secara tepat sifat-sifat suatu individu, keadaan gejala atau kelompok tertentu atau menentukan frekuensi adanya hubungan tertentu antara suatu gejala dengan lainnya dalam suatu masyarakat. Dalam penelitian ini mungkin sudah ada hipotesa mungkin juga belum, tergantung juga dari sedikit banyaknya pengetahuan tentang masalah yang bersangkutan. (Koentjaraningrat, 1990).

Lebih lanjut Soeryono berpendapat bahwa : Diskriptif adalah merupakan penelitian yang dimaksudkan untuk memberikan data yang seteliti mungkin tentang manusia, keadaan atau kejala-gejala lainnya. (Soekanto, 1984).

Berdasarkan pengertian tersebut peneliti menarik pengertian bahwa diskriptif adalah menggambarkan suatu keadaan yang teliti maupun segala sesuatu yang terkait dengan obyek penelitian. Dalam penelitian ini peneliti bermaksud mengetahui faktor-faktor produksi yang berpengaruh terhadap 
produksi padi dan alasan petani dalam satu tahun selalu menanam tanaman padi. Di Desa Glonggong, Kecamatan Gondang, Kabupaten Sragen.

\section{Metode Penentuan Daerah Penelitian}

Metode penentuan daerah dilakukan secara purposive (sengaja) yaitu teknik penentuan suatu daerah berdasarkan pertimbangan tertentu. Daerah yang dijadikan tempat penelitian adalah Desa Glonggong, Kecamatan Gondang, Kabupaten Sragen. Pemilihan Desa Glonggong karena kebanyakan petani disana dalam satu Tahun Selalu Menanam Tanaman Padi.

\section{Cara Pengambilan Data}

Wawancara dan Pencatatan.

Pengambilan sampel petani secara acak sederhana. Jumlah sampel sebanyak 20 petani pemilik penggarap.

\section{Metode Analisis Data}

Untuk mengkaji faktor-faktor produksi usahatani padi dengan rumus sbb :

$\mathrm{Y}=\mathrm{b}_{0}+\mathrm{b}_{1} \mathrm{x}_{1}+\mathrm{b}_{2} \mathrm{x}_{2}+\mathrm{b}_{3} \mathrm{x}_{3}+\mathrm{b}_{4} \mathrm{x}_{4}$

Keterangan :

$\mathrm{Y}=$ Produksi usahatani padi

$\mathrm{b}_{0}=$ Nilai konstanta

$\mathrm{x}_{1}=$ Luas lahan garapan

$\mathrm{x}_{2}=$ Pendidikan formal petani (tahun)

$\mathrm{x}_{3}=$ Penggunaan pupuk (rupiah)

$\mathrm{x}_{4}=$ Penggunaan obat $\quad$ (rupiah)

$\mathrm{b}_{1} \mathrm{~s} / \mathrm{d} \mathrm{b}_{4}=$ Koefisien regresi variabel bebas $\mathrm{x}_{1}$ sampai dengan $\mathrm{x}_{4}$ Untuk mengetahui petani selalu menanam tanaman padi, dengan membuat pertanyaan-pertanyaan kepada petani, kenapa petani dalam satu tahun selalu menanam tanaman padi. 


\section{HASIL DAN PEMBAHASAN}

\section{Hasil Penelitian}

Untuk mengetahui pengaruh faktor-faktor produksi usahatani padi terhadap hasil produksi padi digunakan analisis statistik model regresi linier berganda.

1. Pengaruh faktor-faktor produksi usahatani padi terhadap hasil produksi padi.

Hasil produksi usahatani padi secara bersama-sama dipengaruhi oleh beberapa faktor-faktor produksi usahatani padi yang meliputi : luas lahan, pendidikan petani, penggunaan pupuk, dan penggunaan obat.

Untuk mengetahui faktor-faktor produksi secara bersama-sama berpengaruh terhadap hasil produksi usahatani digunakan uji statistik F.

Hasil analisis pengaruh faktor-faktor produksi secara bersama-sama terhadap produksi usahatani dapat dilihat pada tabel 1.

Tabel 1. Analisis Varians Pengaruh Faktor - Faktor Produksi Usahatani Padi Secara Bersama-Sama Terhadap Hasil Produksi Usahatani Padi Di Desa Glonggong.

\begin{tabular}{lccccc}
\hline $\begin{array}{c}\text { Sumber } \\
\text { varians }\end{array}$ & $\begin{array}{c}\text { Jumlah } \\
\text { kuadrat }\end{array}$ & $\begin{array}{c}\text { Derajad } \\
\text { bebas }\end{array}$ & $\begin{array}{c}\text { Rata-rata } \\
\text { kuadrat }\end{array}$ & F Hitung & F Tabel \\
\hline Regresi & 1.132 & 4 & 2.830 & 7.483 & $.002 * *$ \\
Residu & 5.672 & 15 & 3.781 & & \\
\hline Total & 1.699 & 19 & & & \\
\hline
\end{tabular}

Sumber Data : Analisis data primer

Keterangan :

** = sangat nyata pada tingkat kepercayaan $2 \%$

Dari tabel diatas dapat diketahui bahwa F Hitung sebesar 7.483 dan F Tabel sebesar .002, berarti bahwa F Hitung lebih besar dari pada F Tabel.

Ini menunjukkan bahwa semua faktor-faktor produksi usahatani yang diteliti secara bersama-sama berpengaruh sangat nyata terhadap hasil produksi usahatani padi pada tingkat kepercayaan $2 \%$.

Untuk mengetahu besarnya varibel bebas yang secara bersama-sama digunakan bisa mempengaruhi hasil produksi usahatani padi dapat dillihat 
dari nilai koefisien determinasi $\left(\mathrm{R}^{2}\right)$. Nilai $\mathrm{R}^{2}$ dalam penelitian ini sebesar .666 dari angka tersebut dapat dijelas bahwa 66.60\% perubahan variabel Y (hasil produksi usahatani padi) disebabkan oleh perubahan variabel $\mathrm{X}_{1}$ (luas lahan), $\mathrm{X}_{2}$ (pendidikan petani), $\mathrm{X}_{3}$ (penggunaan pupuk), dan $\mathrm{X}_{4}$ penggunaan obat. Sisanya yang $33.40 \%$ disebabkan oleh variabel lain yang tidak dimasukkan dalam model penelitian ini. Jadi selain pengaruh dari variabel yang dimasukkan dalam penelitian ini, hasil produksi usahani padi masih dipengarahi oleh faktor-faktor yang tidak dimasukkan dalam model penelitian.

2. Pengaruh masing-masing faktor produksi usahatani padi terhadap hasil produksi uhasatani padi.

Hasil analisis pengaruh masing-masing faktor produksi usahatani padi terhadap hasil produksi ushatani padi dapat dilihat pada tabel 2.

Tabel 2. Pengaruh Masing-Masing Faktor Produksi Usahatani Padi Terhadap Hasil Produksi Usahatani Padi.

\begin{tabular}{lcccc}
\hline \multicolumn{1}{c}{ Variabel } & Nilai & T. Hitung & T. Tabel & Ket. \\
\hline Konstanta & -4.837 & -.565 & .581 & $\mathrm{~ns}$ \\
Luas lahan $\left(\mathrm{X}_{1}\right)$ & 2295.660 & 3.883 & .001 & $* *$ \\
Pendidikan Petani $\left(\mathrm{X}_{2}\right)$ & 129600.095 & .203 & .842 & $\mathrm{~ns}$ \\
Penggunaan pupuk $\left(\mathrm{X}_{3}\right)$ & .174 & .165 & .871 & $\mathrm{~ns}$ \\
Penggunaan obat $\left(\mathrm{X}_{4}\right)$ & -3.680 & -.153 & .881 & $\mathrm{~ns}$ \\
\hline
\end{tabular}

Sumber data : analilsis data primer

Keterangan :

** = Sangat nyata pada tingkat kepercayaan $1 \%$

Dari tabel diatas dapat diketahui bahwa :

1. Luas lahan garapan $\left(\mathrm{X}_{1}\right)$.

Luas lahan garapan mempunyai hubungan positif dan berpegaruh sangat nyata terhadap hasil produksi usahatani padi.

2. Pendidikan petani $\left(\mathrm{X}_{2}\right)$.

Pendidikan petani mempunyai hubungan positif dan berpengaruh tidak nyata (ns) terhadap hasil produksi usahatani padi . 
3. Penggunaan pupuk $\left(\mathrm{X}_{3}\right)$.

Penggunaan pupuk mempunyai hubungan positif dan berpengaruh tidak nyata (ns) terhadap hasil produksi usahatani padi.

4. Penggunaan obat $\left(\mathrm{X}_{4}\right)$.

Penggunaan obat mempunyai hubungan negatif dan berpengaruh tidak nyata (ns) terhadap hasil produksi usahatani padi.

\section{Pembahasan.}

2.1. Dari hasil analisis uji F menunjukkan bahwa nilai F hitung lebih besar dari nilai $\mathrm{F}$ tabel pada tingkat kepercayaan $2 \%$, sehingga faktor-faktor produksi usahatani padi secara bersama-sama memberikan pengaruh sangat nyata terhadap hasil produksi usahatani padi.

Sedangkan nilai koefisien determinasi $\left(\mathrm{R}^{2}\right)$ sebesar 0.666 , ini berarti bahwa $66.60 \%$ hasil produksi usahatani padi secara bersama-sama dipengaruhi oleh luas lahan, pendidikan petani, penggunaan pupuk, dan penggunaan obat. Sedangkan $33.40 \%$ hasil produksi usahatani padi dipengaruhi oleh faktor-faktor lain yang tidak dimasukkan dalam penelitian ini.

Pengaruh dari masing-masing faktor produksi usahatan padi menunjukkan bahwa luas lahan berbengaruh sangat nyata terhadap hasil produksi usahatani padi. Sedangkan pendidikan petani, penggunaan pupuk, dan penggunaan obat berpengaruh tidak nyata (ns) terhadap hasil produksi usahatani padi.

Luas lahan garapan yang dimiliki petani memberikan pengaruh yang sangat nyata terhadap hasil produksi usahatani padi. Luas lahan garapan yang dimiliki petani menentukan besarnya skala usaha serta produksi panen yang akhirnya akan menentukan besarnya hasil produksi usahatani padi.

Lahan merupakan media yang digunakan tanaman pertanian untuk tumbuh dan berkembang, yang didalamnya terdapat zat-zat mineral serta unsur hara yang dibutuhkan oleh tanaman. Lahan di daerah penelitian 
termasuk jenis tanah grumusol dan merupakan tanah pertanian datar serta memiliki kesuburan fisik yang cukup baik. Dengan keadaan tanah tersebut, tanaman padi yang ditanam di daerah tersebut sudah mampu tumbuh dan berproduksi. Artinya lahan di daerah penelitian sebagai salah satu faktor produksi usahatani padi sudah mampu memberikan pengaruh terhadap besarnya hasil produksi usahatani padi.

Pendidikan petani, penggunaan pupuk, dan penggunaan obat berpengaruh tidak nyata (ns) terhadap hasil produksi usahatani padi hal ini dapat dijelaskan bahwa rata-rata pendidikan petani sudah mencapai Sekolah Menengah Pertama (SMP). Akan tetapi seorang petani yang berpendidikan tinggi, belum tentu mempunyai pengalaman yang lebih baik dalam berusahatani. Sebagian besar petani sudah memiliki televisi (TV), maka mereka dapat memperoleh pengetahuan dan inofasi-inofasi baru dari televisi (TV) atau media massa lain. Juga dari kelompok-kelompok tani yang ada di daerahnya, khususnya informasi yang diperoleh dari PPL di daerah setempat.

Penggunaan pupuk dan penggunaan obat berpengaruh tidak nyata (ns) terhadap hasil produksi usahatani padi. Hal ini karena kegiatan berusahatani padi sudah merupakan kewajiban bagi petani untuk memenuhi kebutuhan hidup sebagai mata pencaharian pokok. Kegiatan ini sudah dilaksanakan turun temurun atau bertahun-tahun. Oleh karena itu faktor pengguaan pupuk dan penggunaan obat merupakan kegiatan yang harus dilaksanakan. Sehingga petani kadang tidak memperhatikan dosis dan banyaknya obat atau pestisida yang digunakan. Sehingga penggunaan pupuk dan penggunaan obat berpengaruh tidak nyata terhadap hasil produksi usahatani padi.

2.2. Hasil penelitian alasan petani dalam 1 tahun selalu menanam tanaman padi yaitu sebagai berikut :

1. Tanahnya subur cocok untuk tanaman padi.

2. Pengairannya baik dan lancar. 
3. Menanam padi mudah dalam pengelolaannya.

4. Merawat tanaman padi mudah.

5. Beras merupakan makanan pokok.

6. Menanam padi sudah merupakan tradisi turun temurun dan mengikuti lingkungan.

7. Hasil tanaman padi dapat memenuhi kebutuhan sehari-hari atau keluarga.

8. Hasil tanaman padi lebih baik dari pada tanaman lain.

9. Pendapatan dari menanam tanaman padi sangat bagus atau menguntungkan.

10. Kalau sudah menanam padi tidak usah membeli beras yang merupakan makanan pokok.

\section{KESIMPULAN}

1. Faktor-Faktor Produksi Usahatani Padi yaitu luas lahan garapan, pendidikan petani, penggunaan pupuk dan penggunaan obat secara bersama-sama memberikan pengaruh yang sangat nyata terhadap hasil produksi usahatani padi.

2. Luas lahan garapan petani berpengaruh sangat nyata terhadap hasil produksi usahatani padi.

3. Pendidikan petani, penggunaan pupuk dan penggunaan obat berpengaruh tidak nyata (ns) terhadap hasil produksi usahatani padi.

4. Alasan petani dalam 1 tahun selalu menanam tanaman padi :
a. Tanahnya subur.
b. Pengairannya baik dan lancar.
c. Menanam tanaman padi mudah.
d. Beras merupakan makanan pokok.
e. Menanam tanaman padi merupakan tradisi atau turun temurun.
f. Hasil tanaman padi bagus atau menguntungkan.
g. Kalau sudah menanam padi tidak usah membeli beras yang merupakan kebutuhan keluarga sehari-hari.




\section{DAFTAR PUSTAKA}

IDA Zainal, 2013. Tanaman Padi (Oryza sativa L.) digilib.unila.ac.id.

Koentjaraningrat, 1990. Metode Penelitian Masyarakat, Jakarta.Gramedia.

Soekanto, Soeyono. 1984. Pengantar Penelitian Hukum . Jakarta. UI Press.

Soekartawi, 1995, Analisis Usahatani, Jakarta : Penerbit Universitas Indonesia.

Sudalmi, Endang Sri, 2012, Ekonomi Pertanian, Surakarta : Unisri Press.

Sundari, Mei Tri, 2011, Analisis Biaya Dan Pendapatan Usaha Tani Wortel Di Kabupaten Karanganyar. http://agribisnis.fp.uns.ac.id/wp-content/uploads /2013/10/07-Mei-Tri-Sundari-Analisis-Biaya-Dan-Pendapatan-Usaha-TaniWortel-Di-Kabupaten-Karanganyar.pdf [27 September 2014]

Suratiyah, Ken, 2002, Ilmu Usaha Tani, Jakarta : Penebar Swadaya.

Tohir, A. Kaslan, 1991, Seuntai pengetahuan tentang usahatani Indonesia Bagian Satu. Unsur-unsur pembentukan dan ciri-ciri usahatani Indonesia, Jakarta : Bina Aksara 